\title{
КОМП'ЮТЕРНЕ МОДЕЛЮВАННЯ СПІВІСНУВАННЯ ВІРУСНИХ ШТАМІВ: НЕПЕРЕДБАЧУВАНІСТЬ ЧЕРЕЗ НЕЛІНІЙНІ ЯВИЩА
}

\author{
В. Марценюк, М. Карпінський, А. Клос-Вітковська, О. Весельська, \\ I. Андрущак ${ }^{1}$, А. Сверстюк², О. Кучвара² \\ Університет Бєльсько-Бяли, Республіка Польща \\ 1Луцький національний технічний університет \\ 2 Тернопільський національний медичний університет \\ імені І. Я. Горбачевського МОЗ України
}

\begin{abstract}
У роботі представлено модель взаємодії двох штамів вірусу. Модель ґрунтується на системі диференціальних рівнянь і враховує популяції уразливих, вперше та повторно інфрікованих осіб відповідно до двох штамів. На основі чисельного моделювання отримано складні хаотичні розв'язки моделі. Отримано умови на параметри розповсюдження інорекційного захворювання, що забезпечують стійкі ендемічні стани.
\end{abstract}

Ключові слова: епідеміологія, ендемічний стан, стабільність, детермінований хаос, нелінійний аналіз.

\section{COMPUTATIONAL MODELING OF COEXISTENCE OF VIRUS STRAINS: UNPREDICTABILITY BECAUSE OF NONLINEAR PHENOMENA}

\author{
V. Martsenyuk, M. Karpinski, A. Klos-Witkowska, O. Veselska, \\ I. Andrushchak ${ }^{1}$, A. Sverstiuk², O. Kuchvara ${ }^{2}$ \\ University of Bielsko-Biala, the Republic of Poland \\ ${ }^{1}$ Lutsk National Technical University \\ 2 Ivan Horbachevsky Ternopil National Medical University
}

\begin{abstract}
Background. The model of interaction of two strains of the virus is considered in the paper. The model is based on a system of differential equations and takes into account populations of susceptible, first-time and re-infected individuals across two strains. The objective of the work was to offer and investigate the model of coexistence of two virus strain from viewpoint of stability, periodicity and predictability of the epidemiological curves.

Materials and methods. Results. As a mathematical object a system of seven ordinary differential equations was proposed. At the same time, more sophisticated models based on delayed differential equations, stochastic differential equations, partial differential derivative equations can be used in the study of the spatial spread of the epidemic. Of great importance in all these cases is a qualitative study of the nonlinear behavior of the model. We see from numerical studies that at certain values of the parameters of the solution, large values of periods are obtained. Such solutions are called quasi-periodic and correspond to a situation called in the theory of dynamical systems as "deterministic chaos".

The obtained solution trajectories of the proposed model also indicate the complexity of epidemic prediction. Even in the simplest case of describing a model based on deterministic equations, we get chaotic solutions. This is due to the complexity of nonlinear interaction between subpopulations of the epidemiological model.

Conclusions. The model of coexistence of two strains of viruses was investigated. Such a model can be used to investigate the spread of infectious diseases. Of great importance in the model are the subpopulations of individuals susceptible to the virus, given its two strains. It is undoubted that further studies should address the use of a seasonal spread of epidemiologically relevant disease that is consistent with the use of non-stationary dynamic models. Also of great importance is the inclusion in the model of populations of symptomatically and asymptotically infected persons.
\end{abstract}

Key words: epidemiology, endemic state, stability, deterministic chaos, nonlinear analysis. 


\title{
КОМПЬЮТЕРНОЕ МОДЕЛИРОВАНИЕ СОСУЩЕСТВОВАНИЯ ВИРУСНЫХ ШТАММОВ: НЕПРЕДСКАЗУЕМОСТЬ ЧЕРЕЗ НЕЛИНЕЙНЫЕ ЯВЛЕНИЯ
}

\author{
В. Марценюк, М. Карпинский, А. Клос-Витковская, А. Весельская, \\ И. Андрущак ${ }^{1}$, А. Сверстюк ${ }^{2}$, А. Кучвара ${ }^{2}$ \\ Университет Бельско-Бялы, Республика Польша \\ 1 Луцкий национальный технический университет \\ 2 Тернопольский национальный медицинский университет \\ имени И. Я. Горбачевского МЗ Украины
}

\begin{abstract}
В статье рассмотрена модель взаимодействия двух штаммов вируса. Модель базируется на системе диффреренциальных уравнений и учитывает популяции восприимчивых к заражению, впервые и повторно зараженных лиц двумя штаммами. На основе численного моделирования получены сложные хаотические решения модели. Получены условия распространения инфекционного заболевания при стабильных эндемических условиях.

Ключевые слова: эпидемиология, эндемическое состояние, стабильность, детерминированный хаос, нелинейный анализ.
\end{abstract}


Introduction. Vaccines are being developed for annual seasonal epidemics. Flu strains are mutated very quickly and the question, of which most likely strain of influenza is invaded, is solved annually. Distributed vaccines protect against the three strains that are considered the most dangerous. However, if the strain is radically different from previously known strains, then the vaccine has little or no protection, which poses a threat of a pandemic. Since it takes at least 6 months to develop a vaccine that can protect against a new strain, there is no ready vaccine to protect against the attack of a new pandemic strain. There are antiviral drugs for the treatment of pandemic influenza, they also have some preventive effect, but this effect will only occur when providing antiviral treatment. Therefore, it is important to find ways of effective vaccination in the presence of different strains of the virus.

In previous studies [1-4], we have studied the use of models based on delayed differential equation systems in the case of a single strain of virus with a population of symptomatically and symptomatically infected individuals, paying particular attention to endemic stability studies. For this purpose, linearization methods and the direct method of lyapunay were used. At the same time, the model of interaction of subpopulations in the case of the spread of several virus strains and the question of nonlinear analysis of such models are of considerable interest [5-8].

Thus the objective of the work is to offer and investigate the model of coexistence of two virus strain from viewpoint of stability, periodicity and predictability of the epidemiological curves.

Theoretical Results. The model is intended to describe the spread of various strains of the virus (such as pandemic and seasonal influenza). The model makes assumptions.

1. The compartments of latent persons are not considered.

2. It is believed that the course of the flu is necessarily accompanied by the presence of symptoms. That is, there is no compartment asymptomatically infected.

3. The total population size of $N$ is considered constant.

So, a transition state diagram is considered (see Fig. 1):

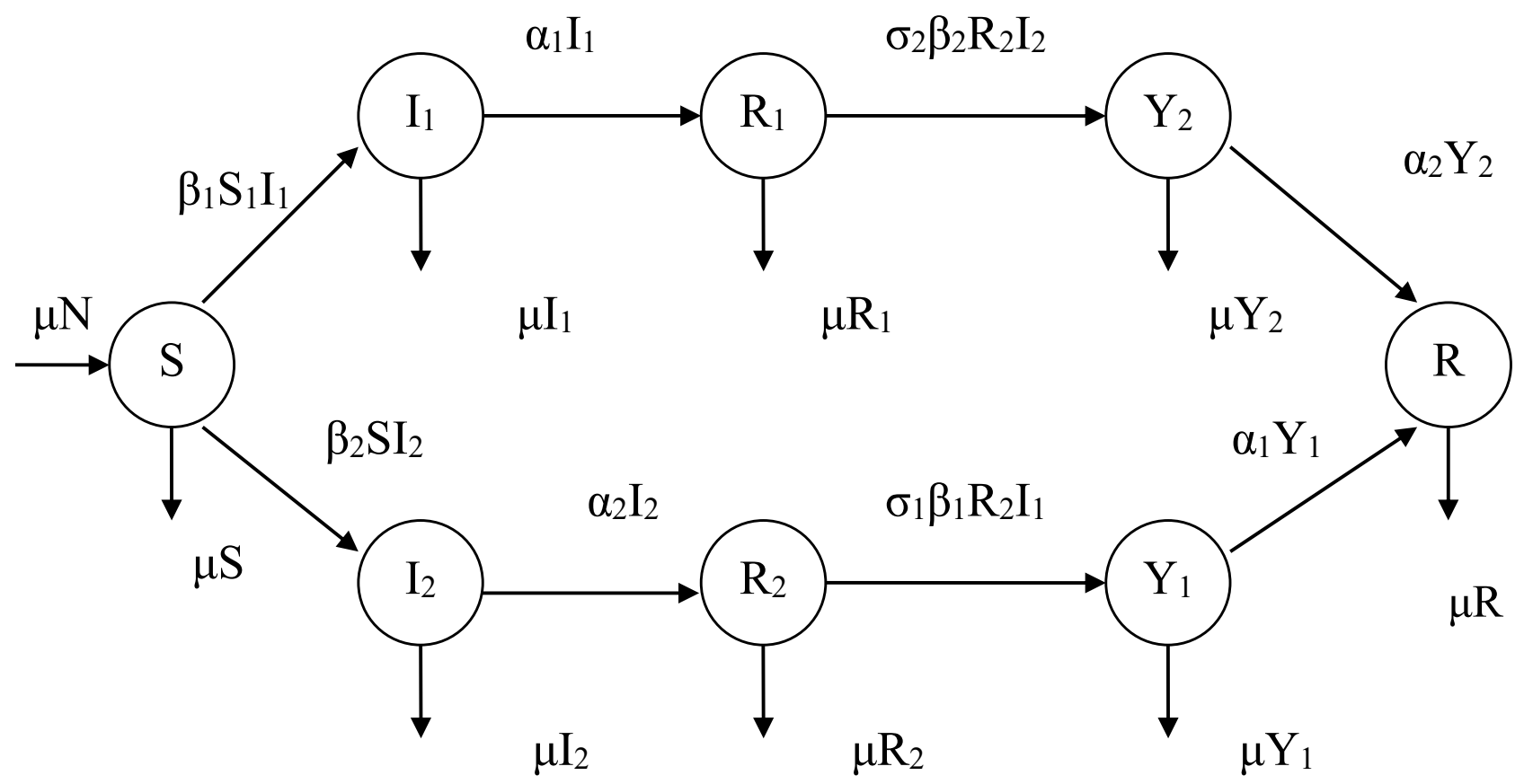

Figure 1. Transition diagram for two virus strains

Here we have compartments that meet subpopulations $S$ - susceptible, $I_{1}$ - infected with the 1 st strain of the virus, $I_{2}$ - infected with the 2nd strain of the virus, $R_{1}$ - recovered after the 1 st strain of the virus,
$R_{2}$ - recovered after the 2nd strain of the virus, $Y_{1}$ - re-infected (but already the first strain), $Y_{2}$ - reinfected (but already the second strain of the virus), $R$ - recovering after double infection of persons. 
On its basis we have a system:

$S^{\prime}=\mu(N-S)-\left(\beta_{1} I_{1}+\beta_{2} I_{2}\right) S$,

$I^{\prime}=\beta_{i} S I_{i}-\left(\mu+\alpha_{i}\right) I_{i}, i=1,2$,

$R_{i}^{\prime}=\alpha_{i} I_{i}-\left(\mu+\sigma_{j} \beta_{j} I_{j}\right) R_{i} ; i, j=1,2, i \neq j$,

$Y_{i}^{\prime}=\theta_{i} \beta_{i} R_{j} I_{i}-\left(\mu+\alpha_{i}\right) Y_{i} ; i, j=1,2, i \neq j$,

$R^{\prime}=\alpha_{1} Y_{1}+\alpha_{2} Y_{2}-\mu R$.

Here for any $t$ :

$S+I_{1}+I_{2}+R_{1}+R_{2}+Y_{1}+Y_{2}+R=N$,

where biologically significant region is

$\Omega=\left\{\left(S, I_{1}, I_{2}, R_{1}, R_{2}, Y_{1}, Y_{2}\right) \in\right.$

$\left.R_{+}^{7} \mid S+I_{1}+I_{2}+R_{1}+R_{2}+Y_{1}+Y_{2} \leq N\right\}$.

Determine the equilibrium states of system (1) belonging to the boundary $\Omega$ from the system of algebraic equations:

$\mu(N-S)-\left(\beta_{1} I_{1}+\beta_{2} I_{2}\right) S=0$,

$\beta_{i} S I_{i}-\left(\mu+\alpha_{i}\right) I_{i}=0$,

$\alpha_{i} I_{i}-\left(\mu+\sigma_{j} \beta_{j} I_{j}\right) R_{i}=0$,

$\theta_{i} \beta_{i} R_{j} I_{i}-\left(\mu+\alpha_{i}\right) Y_{i}=0$,

$i, j=1,2, i \neq j$

We have three equilibrium states:

$$
\begin{aligned}
& E_{0}=(N, 0,0,0,0,0,0), \\
& E_{1}=\left(S_{1}^{*}, I_{1}^{*}, 0, R_{1}^{*}, 0,0,0\right), \\
& E_{2}=\left(S_{2}^{*}, 0, I_{2}^{*}, 0, R_{2}^{*}, 0,0\right) .
\end{aligned}
$$

Here:

$$
\begin{aligned}
& S_{1}^{*}=\frac{\mu+\alpha_{1}}{\beta_{1}}, I_{1}^{*}=\frac{\mu\left(N \beta_{1}-\mu-\alpha_{1}\right)}{\beta_{1}\left(\mu+\alpha_{1}\right)}, \\
& R_{1}^{*}=\frac{\alpha_{1}\left(N \beta_{1}-\mu-\alpha_{1}\right)}{\beta_{1}\left(\mu+\alpha_{1}\right)} .
\end{aligned}
$$

$$
\begin{aligned}
& S_{2}^{*}=\frac{\mu+\alpha_{2}}{\beta_{2}}, I_{2}^{*}=\frac{\mu\left(N \beta_{2}-\mu-\alpha_{2}\right)}{\beta_{2}\left(\mu+\alpha_{2}\right)}, \\
& R_{2}^{*}=\frac{\alpha_{2}\left(N \beta_{2}-\mu-\alpha_{2}\right)}{\beta_{2}\left(\mu+\alpha_{2}\right)} .
\end{aligned}
$$

We introduce the notions of the basic reproduction numbers:

$\mathfrak{R}_{1}=\frac{\beta_{1} N}{\mu+\alpha_{1}}, \Re_{2}=\frac{\beta_{2} N}{\mu+\alpha_{2}}$,

Hence,

$$
\begin{aligned}
& S_{1}^{*}=\frac{N}{R_{1}^{*}}, I_{1}^{*}=\frac{\mu}{\beta_{1}}\left(R_{1}-1\right), R_{1}^{*}=\frac{\alpha_{1}}{\beta_{1}}\left(R_{1}-1\right), \\
& S_{2}^{*}=\frac{N}{R_{2}^{*}}, I_{2}^{*}=\frac{\mu}{\beta_{2}}\left(R_{2}-1\right), R_{2}^{*}=\frac{\alpha_{2}}{\beta_{2}}\left(R_{2}-1\right) .
\end{aligned}
$$

Equilibrium states have the following epidemiological interpretation:

$E_{0}$ - the state of absence of the disease,

$E_{1}$ - the presence of strain 1 only,

$E_{2}$ - the presence of strain 2 only.

Let us denote $\mathfrak{R}_{0}=\max \left\{\mathfrak{R}_{1}, \mathfrak{R}_{2}\right\}$. If $\mathfrak{R}_{0} \leq 1$ then it is the only equilibrium state in $\Omega$. If $\Re_{0}>1$ then, either $E_{1}$, or $E_{2}$, or both belong $\Omega$.

Fig. 2, 3 show the regions of existence and stability of equilibrium states $E_{\mathrm{i}}$.

Experimental results. Consider the system (1) for the values of parameters

$$
\begin{aligned}
& N=10^{5}, \mu=0.005, \beta_{1}=0.4 \cdot 10^{-5}, \beta_{2}=0.3 \cdot 10^{-5}, \\
& \alpha_{1}=0.1428, \alpha_{2}=0.1428, \sigma_{1}=1, \sigma_{2}=1
\end{aligned}
$$

Note that we get:

$$
\begin{aligned}
& \mathfrak{R}_{1}=\frac{\beta_{1} N}{\mu+\alpha_{1}}=\frac{4 \cdot 10^{-6} \cdot 10^{5}}{5 \cdot 10^{-3}+0,1428}=\frac{0,4}{0,1478}=2,706, \\
& \mathfrak{R}_{2}=\frac{\beta_{2} N}{\mu+\alpha_{2}}=\frac{3 \cdot 10^{-6} \cdot 10^{5}}{5 \cdot 10^{-3}+0,1428}=\frac{0,3}{0,1478}=2,0298 .
\end{aligned}
$$




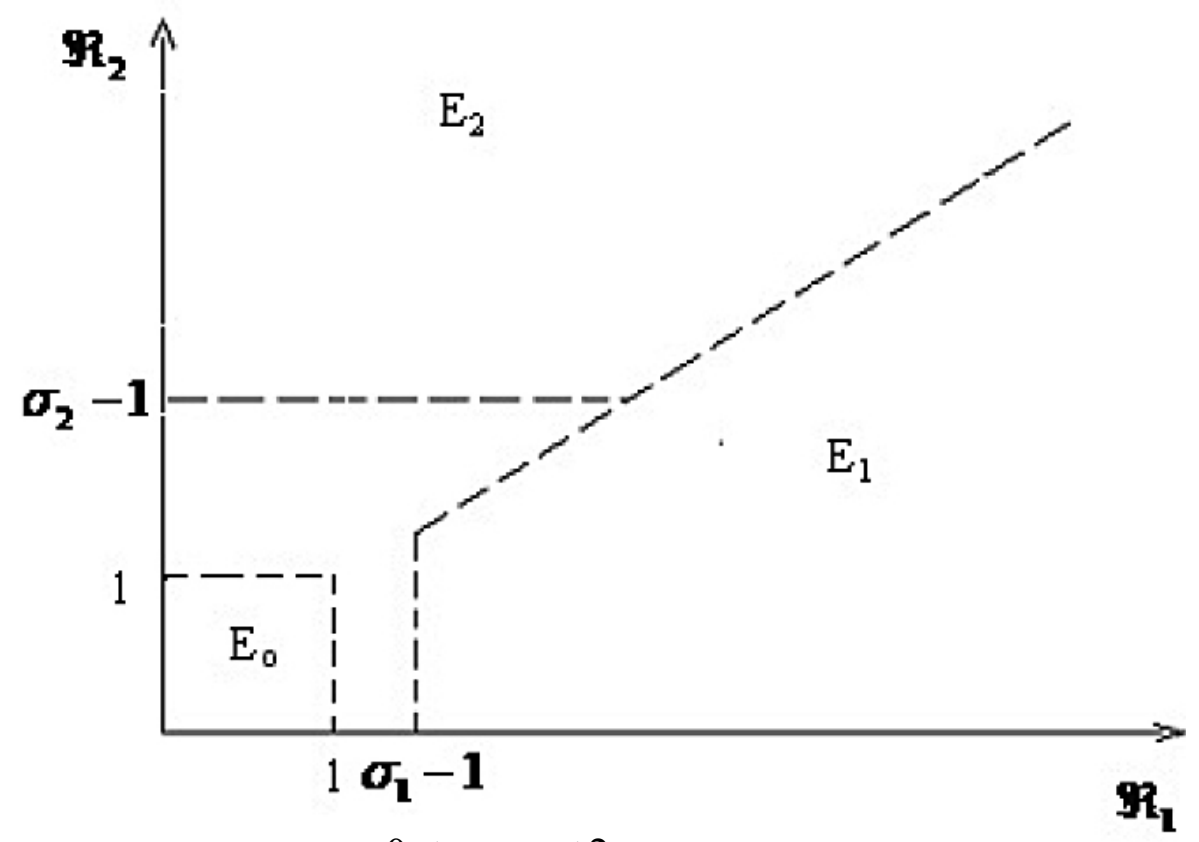

Fig. 2. Stability regions in the case if $0 \leq \sigma_{1}, \sigma_{2} \leq 2$

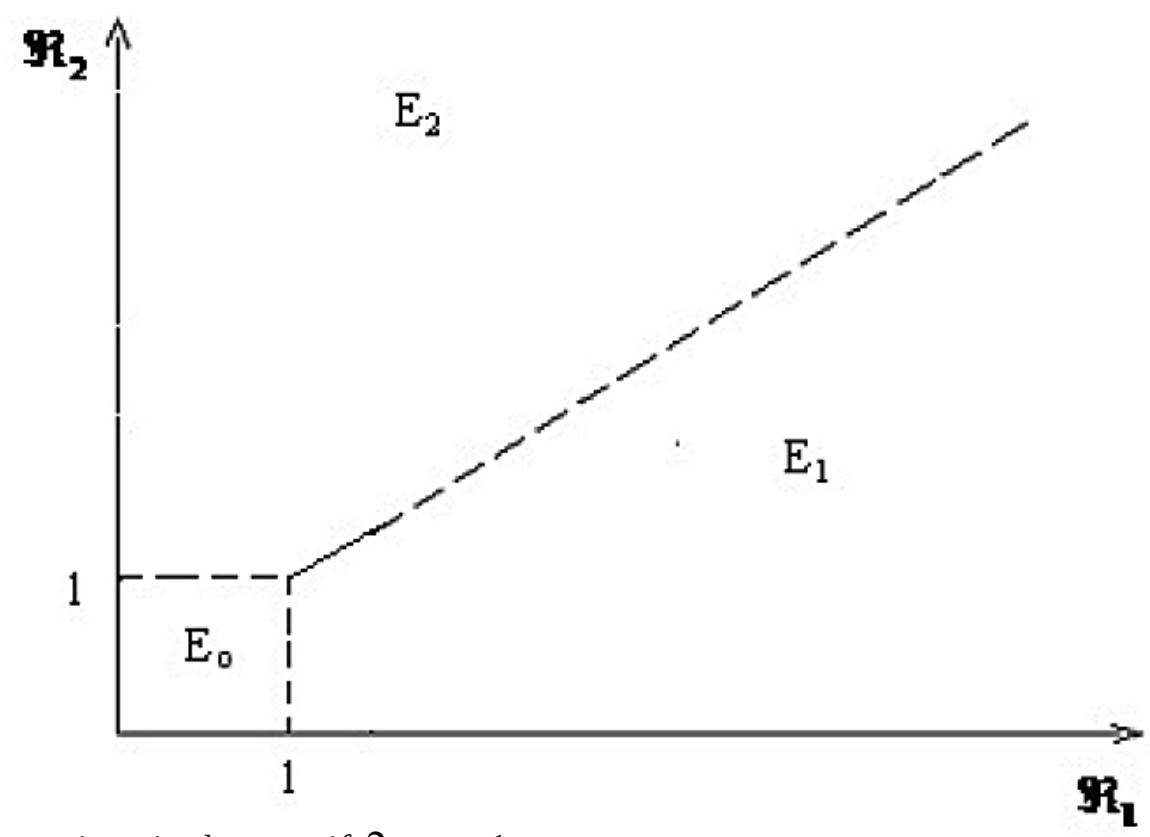

Fig. 3. Stability regions in the case if $2<\sigma_{1} \leq \sigma_{2}$

That is $\mathfrak{R}_{1}>\mathfrak{R}_{2}$ and all the conditions, which were mentioned above, hold. Computational modeling of (1) has been implemented (see Fig. 4).

We see a complex nonlinear behavior of the system trajectory. Such nonlinear behavior is caused by a change in a number of model parameters. The fig. 4 shows the effect of changes in the incubation period on the trajectory and solutions of the equation system.
We see that increasing the incubation period for the two strains of virus under consideration affects the complexity of the trajectories obtained. It should be noted that for small values of the incubation period, the obtained solutions tend to a certain melt value called the endemic solution. At the same time, an increase in the incubation period leads to a periodic solution of the system. Such phenomena in the theory of dynamical systems have been called bifurcation, which occurs when the values of the 

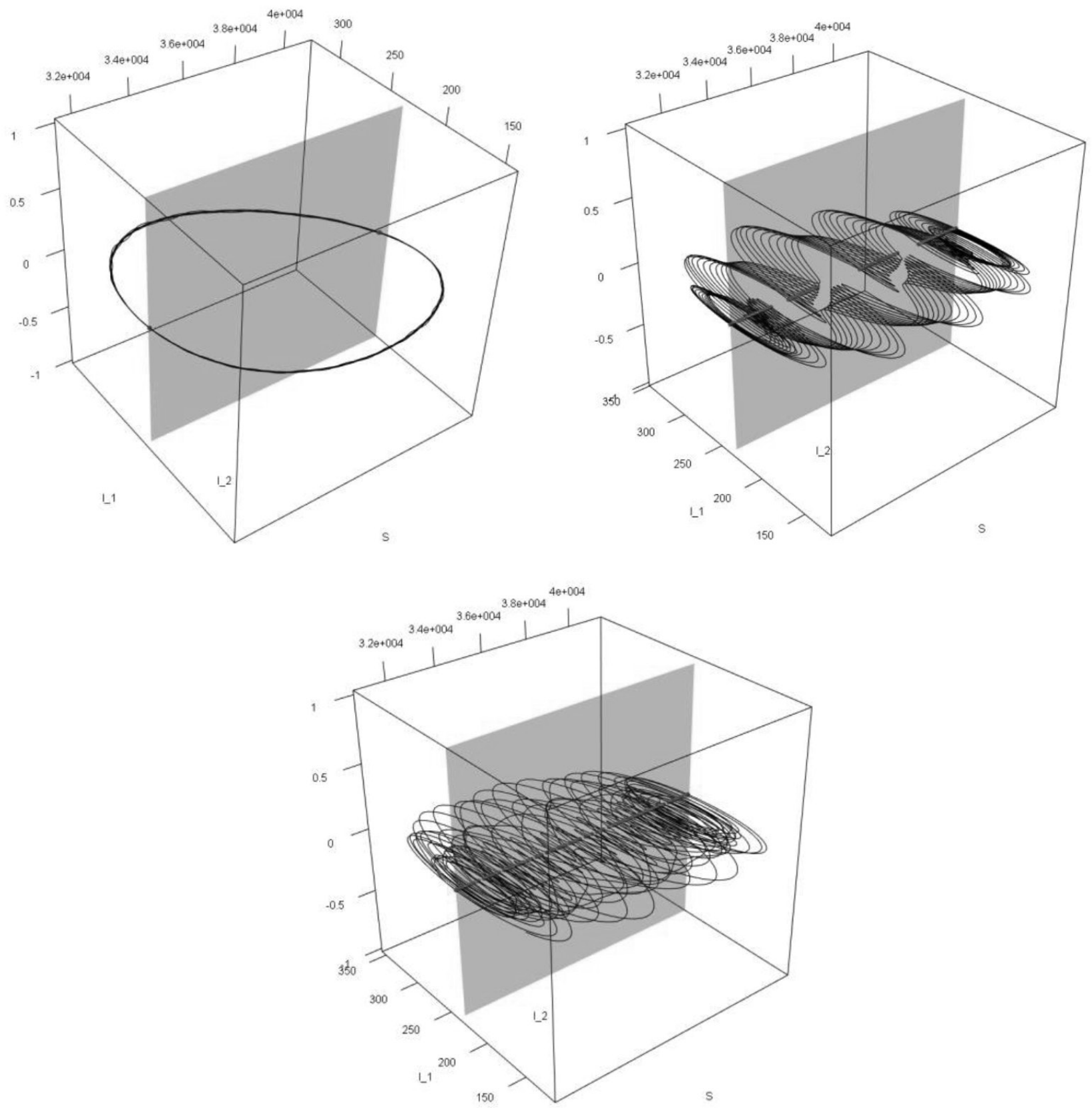

Fig. 4. Phase plot of $S, I_{1}$, and $I_{2}$ during 8000 days

system parameters change and affect the change in the qualitative behavior of the whole model.

In this case, we transform from a steady endemic focus to a limit cycle. Such a limit cycle corresponds to the situation of periodic epidemics. The impact of other parameters on the change in the qualitative behavior of system trajectories should also be investigated. A further change in the incubation period affects the complexity of such a periodic solution. From a certain value of the incubation periods corresponding to different strains of the virus, there is a doubling of the period, and then the period increases 4 times, 8 times and so on.
Conclusions. Therefore, the model of coexistence of two strains of viruses was investigated. Such a model can be used to investigate the spread of infectious diseases. Of great importance in the model are the subpopulations of individuals susceptible to the virus, given its two strains.

It is clear that the model can be developed for the cases of three strains, four, etc. In this case, a system of seven ordinary differential equations was proposed as a mathematical object. At the same time, more sophisticated models based on delayed differential equations, stochastic differential equations, partial differential derivative equations can be used in the 
study of the spatial spread of the epidemic. Of great importance in all these cases is a qualitative study of the nonlinear behavior of the model. We see from numerical studies that at certain values of the parameters of the solution, large values of periods are obtained. Such solutions are called quasi-periodic and correspond to a situation called in the theory of dynamical systems as «deterministic chaos».

The obtained solution trajectories of the proposed model in fig. 4 also indicate the complexity of epidemic prediction. Even in the simplest case

\section{Література.}

1. On conditions of asymptotic stability in SIR-models of mathematical epidemiology / Martsenyuk V.P., Andrushchak I. Ye., Kuchvara A. M. // Journal of Automation and Information Sciences. — 2011. — № 43. - P. 12.

2. On map and statistical data driven decision making in healthcare organization / Martsenyuk V. P. et al. // International Multidisciplinary Scientific GeoConference: SGEM: Surveying Geology \& mining Ecology Management. — 2018. — № 18. — P. 331-338.

3. Кучвара А. М. Модели популяционной динамики в задачах математической эпидемиологии острых респираторных заболеваний / А. М. Кучвара, А. Г. Наконечний, В. П. Марценюк // Кибернетика и вычислительная техника. — 2010. — Vol. 159. — P. 45-64.

4. Andrushchak I. Ye. Software Implementation of Numerical Method for Optimal Control in Problems of Preventive Medicine / Andrushchak I. Ye. // Journal of Automation and Information Sciences. — 2014. № 46. - P. 8.

5. Martsenyuk V.P..Approach to the Study of Global Asymptotic Stability of Lattice Differential Equations with Delay for Modeling of Immunosensors / Martsenyuk V. P., Sverstiuk A. S., Andrushchak I. Ye. // Journal of Automation and Information Sciences. — 2019. — № 51. — P. 2.

6. Martsenyuk V. On Nonlinear Reaction-Diffusion Model with Time Delay on Hexagonal Lattice / Martsenyuk V., Veselska O. // Symmetry. - 2019. - T. 11, № 6. — P. 758.

7. Martsenyuk V. Stability Investigation of Biosensor Model Based on Finite Lattice Difference Equations. International Conference on Difference Equations and Applications / Martsenyuk V., Klos-Witkowska A., Sverstiuk A. - Springer, Cham, 2018.

8. Martsenyuk V. Computation Model of Cyber-Physical Immunosensor System / Martsenyuk V., Klos-Witkowska A. // IEEE Access. — 2019. — № 7. — P. 62325-62337. of describing a model based on deterministic equations, we get chaotic solutions. This is due to the complexity of nonlinear interaction between subpopulations of the epidemiological model. It is undoubted that further studies should address the use of a seasonal spread of epidemiologically relevant disease that is consistent with the use of non-stationary dynamic models. Also of great importance is the inclusion in the model of populations of symptomatically and asymptotically infected persons.

\section{References.}

1. Martsenyuk, V. P., Andrushchak, I. Ye., Kuchvara, A. M. (2011). On conditions of asymptotic stability in SIR-models of mathematical epidemiology. Journal of Automation and Information Sciences, 43, 12.

2. Martsenyuk, V. P. et al. (2018). On map and statistical data driven decision making in healthcare organization. International Multidisciplinary Scientific GeoConference: SGEM: Surveying Geology \& mining Ecology Management, 18, 331-8.

3. Kuchvara, A. M., Nakonechnyy, A. G., Martsenyuk, V. P. (2010). Modeli populyatsionnoy dinamiki v zadachakh matematicheskoy epidemiologii ostrykh respiratornykh zabolevaniy [Models of population dynamics in the problems of mathematical epidemiology of acute respiratory diseases]. Kibernetika i vychislitel'naya tekhnika (Cybernetics and computing), 159, 45-64. [In Ukrainian].

4. Andrushchak, I. Ye. (2014). Software Implementation of Numerical Method for Optimal Control in Problems of Preventive Medicine. Journal of Automation and Information Sciences, 46, 8.

5. Martsenyuk, V. P., Sverstiuk, A. S., Andrushchak, I. Ye. (2019). Approach to the Study of Global Asymptotic Stability of Lattice Differential Equations with Delay for Modeling of Immunosensors. Journal of Automation and Information Sciences, 51, 2.

6. Martsenyuk, V., Veselska, O. (2019). On Nonlinear Reaction-Diffusion Model with Time Delay on Hexagonal Lattice. Symmetry, 11, 6, 758.

7. Martsenyuk, V., Klos-Witkowska, A., Sverstiuk, A. (2018). Stability Investigation of Biosensor Model Based on Finite Lattice Difference Equations. International Conference on Difference Equations and Applications. Springer, Cham.

8. Martsenyuk, V., Klos-Witkowska, A. (2019). Computation Model of Cyber-Physical Immunosensor System. IEEE Access, 7, 62325-37. 